\title{
Giving Extension Effect On Landslide Disaster Preparedness of Householder's Knowledge And Attitude
}

\author{
Novita Ana Anggraini, Sutrisno, Weni Uswatun Hasanah ${ }^{1}$ \\ ${ }^{1}$ STIKes Surya Mitra Husada, Kediri, East Java, Indonesia \\ Corresponding author : phitphita@gmail.com
}

\begin{abstract}
Background: The high number of disasters in Indonesia pushed against the need for vigilance on the disaster. preparations to be made by civil society organizations, especially scouts, TAGANA or SAR've pretty much done, but preparedness at the family level and the individual is still a lot of efforts increase efforts to improve the preparedness of the family in the face of disaster requires an effort to educate more people, especially in terms of disaster mitigation.

Purpose : The aim of this study was to determine the effect of education on disaster preparedness landslides on knowledge and attitude of the head of the family in the hamlet village Jethi Blimbing Mojo Subdistrict Kediri.

Methods : This research design is pre-experimental with approach to one group pre-post test, the data obtained using questionnaire. The number of samples taken in this research were 78 respondents, by purposive sampling.

Result : Of the total 78 respondents surveyed after being given counseling, 37 respondents (47.4\%) had knowledge of preparedness landslides in enough categories and 47 respondents $(60.3 \%)$ had the attitude of preparedness landslides in the positive category. The analysis in this research for the knowledge using wilcoxon sign rank test statistics obtained $\mathrm{p}=0,000<0,05$ then $\mathrm{H} 0$ is rejected and $\mathrm{H} 1$ accepted. Whereas for the attitude using Mc.Nemar statistic test obtained $\mathrm{p}=0.001<0.05$ then $\mathrm{H} 0$ is rejected and $\mathrm{H} 1$ accepted

Conclusion : By giving periodic counseling and provision of information continuously, it can affect respondents' knowledge about disaster preparedness landslides, because it can affect the stimulus and understand the information provided.
\end{abstract}

Keywords : Preparedness, Knowledge, Attitude, Landslides

How to Cite: Anggraini, N., Sutrisno, S., Hasanah, W. (2018). Giving Extension Effect On Landslide Disaster Preparedness of Householder's Knowledge And Attitude. Journal Of Nursing Practice, 2(1), 58-63. https://doi.org/10.30994/jnp.v2i1.44 


\section{BACKGROUND}

The high number of disasters in Indonesia encourages the need for awareness of disasters, starting with the government that forms the National Disaster Management Agency (BNPB), at the level of the environment stands the Disaster Response Youth Organization (TAGANA). Preparedness is expected to develop at all levels of society, especially at the family level, but at the family level disaster has not become a problem that must be faced together and there are solutions that are specific to each family (Ramli, 2012).

In 2014 the number of landslide victims in Indonesia was 6,785 families with a death toll of 312 people (BNPB Pusat, 2014). For East Java Province in 2014 the highest number of disasters was floods that occurred in 147 locations, wind disasters reached 128 locations and landslides as many as 98 locations, the number of landslide victims in East Java Province in 2014 was 635 households with 12 people killed (East Java Province BPBD, 2014).

The results of the preliminary study conducted on February 16, 2015 in Jethi Hamlet, Blimbing Village, Mojo District, Kediri Regency, have received counseling about disaster preparedness from the BPBD of Kediri Regency and from the Sub-District. Interviews with 7 people revealed that 6 people did not understand the knowledge and attitudes in dealing with landslides. The responsibility for carrying out disaster management activities can be in the form of preparedness, namely: actions that allow governments, organizations, communities, communities and individuals to be able to respond to a disaster situation quickly and accurately (Rante, 2013). The preparations that must be carried out by community organizations, especially Scouts, TAGANA and other Search and Rescue (SAR) Agencies have been done quite a lot, but the readiness at the family and individual levels is still not much done. This condition creates the emergence of dependence on families and individuals at the time of the disaster, so that they cannot carry out anticipation independently and depend more on existing SAR organizations, even though the presence of the organization is uncertain quickly during a disaster (Djafar, 2013). Efforts to improve family preparedness in dealing with disasters require efforts to provide counseling to the community, especially in terms of disaster mitigation (Karnawati, 2005)..

\section{OBJECTIVE}

The general objective of this study was to determine the effect of providing counseling on landslide disaster preparedness on the knowledge and attitudes of the head of the family in Jethi Village, Blimbing Village, Mojo District, Kediri Regency.

\section{METHODS}

The research design used was pre-experimental with one group pre-post test approach. The population in this study were all heads of families in Jethi Village, Blimbing Village, Mojo District, Kediri Regency, totaling 360 families. The sample in this study were some households in Jethi Hamlet as many as 78 respondents.

In this study using purposive sampling sampling technique that is sampling from members of the population in accordance with the criteria that have been previously known by researchers.

The instrument used in this study is a questionnaire sheet. Data processing that has been collected is done by editing, coding, scoring, and tabulating. 
Data analysis used to test knowledge used the Wilcoxon signed rank test and to test the attitude using the Mc Nemar test. With a significance level of 5\%.

\section{RESULTS}

\section{a. Characteristics of Respondents}

Characteristics of research respondents include age, education, occupation, information history and length of stay. There were half of the respondents aged 26-45 years as many as 39 respondents (50\%), elementary level education (SD, SMP) as many as 37 respondents (48\%), working as farmers / farm laborers as many as 26 respondents (33\%), had received information about landslides from officers as many as 31 respondents $(40 \%)$, and have lived in Jethi Hamlet for more than 10 years as many as 48 respondents $(62 \%)$.

b. Variable Characteristics

It is known that before counseling, almost half of the respondents had knowledge about landslide disaster preparedness in the sufficient category, namely 32 respondents $(41.0 \%)$ and attitudes of landslide disaster preparedness in the negative category, namely 44 respondents (56.4\%). While after counseling, almost half of the respondents had knowledge about landslide disaster preparedness in the sufficient category, namely 37 respondents $(47.4 \%)$ and landslide disaster preparedness attitudes in the positive category, namely 47 respondents $(60.3 \%)$.

\section{c. Statistical Test Results}

That prior to counseling almost half of the respondents had knowledge of landslide disaster preparedness in the sufficient category, namely 32 respondents $(41.0 \%)$ and after counseling almost half of the respondents had sufficient knowledge in the category, namely 37 respondents $(47.4 \%$ ) The results of statistical tests using Willcoxon signed rank test showed that the value of $\mathrm{p}=0,000<\alpha=0,05$ so that $\mathrm{H} 0$ was rejected and $\mathrm{H} 1$ was accepted. Whereas for attitudes it is known that before counseling some respondents had a negative attitude, namely 44 respondents $(56.4 \%)$. and after counseling some respondents who have attitudes in the negative category, namely 31 respondents (39.7\%). The results of the statistical test using the McNemar test showed that the value of $\mathrm{p}=0.001<\alpha=0.05$ so that $\mathrm{H} 0$ was rejected and $\mathrm{H} 1$ was accepted.

\section{DISCUSSION}

a Knowledge of the Head of the Family in Jethi Hamlet, Blimbing Village, Mojo District, Kediri Regency Before Being Provided Counseling

Knowledge of the head of the family in Jethi Hamlet, Blimbing Village, Mojo District, Kediri Regency, it was known that before the extension was carried out, almost half of the respondents had knowledge about landslide disaster preparedness in the sufficient category, namely 32 respondents $(41.0 \%)$. Knowledge is a domain that is very important to do a person's actions (Overt Behavior). Age affects a person's catching power, the more it grows, the more the catching power and mindset will develop, so that the knowledge gained will improve (Nursalam, 2008). According to Y.B. Mantra is quoted by Notoatmodjo (2010). In general, the higher the education, the more easily one receives information. Information will have an influence on one's knowledge, knowledge can also be obtained by someone from the information they have received. In addition, work is also a factor that influences knowledge. The more people will get more information (Notoatmodjo, 2007). 
The results of cross tabulation between age and knowledge shows that age 26-45 years old has sufficient knowledge in the category of $33.3 \%$. The result of cross tabulation between education and knowledge shows that most respondents with basic education (elementary, junior high) have knowledge in the less category as many as 20 respondents $(25.6 \%)$. Whereas respondents who have never received information have knowledge about landslide disaster preparedness in the less category, namely 9 respondents $(11.5 \%)$ and the results of tabulation of knowledge with the employment of peasants / farm laborers before extension has knowledge of disaster preparedness in the less category, namely 14 respondents $(17.9 \%)$. This study shows that the majority of respondents have sufficient knowledge, this means that respondents actually already know about disaster preparedness, but their knowledge still does not meet to be used as a basis for disaster preparedness.

b Attitude of the Head of the Family in Jethi Village, Blimbing Village, Mojo District, Kediri Regency Before Being Provided Counseling

The attitude of the head of the family in Jethi Hamlet, Blimbing Village, Mojo District, Kediri District, it was known that before the extension was carried out, almost half of the respondents had the attitude of landslide disaster preparedness in the negative category, namely 44 respondents $(56.4 \%)$.

Attitude is a general evaluation made by man against himself, others, objects or issues which are certain regularities in terms of feelings (affection), thinking (cognition) and predisposing actions (konasi) (Azwar, 2005). Attitudes have a tendency to behave (Notoatmodjo, 2010).

Based on the results of the study it is known that respondents with jobs as farmers / farm laborers have a landslide disaster preparedness attitude in the negative category, namely 18 respondents $(23.1 \%)$. As farmers in general the community has minimal access to information, this causes respondents to respond to disaster preparedness tends to be negative. attitude will be easier to form if personal experience occurs in situations involving emotional factors.

c Knowledge of the Head of the Family in Jethi Village, Blimbing Village, Mojo Subdistrict, Kediri Regency After Being Provided Counseling

Knowledge of the head of the family in Jethi Hamlet, Blimbing Village, Mojo District, Kediri District, was known that after counseling, almost half of the respondents had knowledge about landslide preparedness in the sufficient category, namely 37 respondents $(47.4 \%)$.

Age affects a person's catching power, the more it grows, the more the catching power and mindset will develop, so that the knowledge gained will improve (Nursalam, 2008). In addition, the higher the education of a person, the easier it is to receive information. Information will give effect to one's knowledge, knowledge can also be obtained by someone from the information they have received (Notoatmodjo, 2010).

Respondents' knowledge after the extension was in the sufficient category. The low level of understanding received by respondents was caused by many things including respondents with basic level education after being educated having knowledge of landslide preparedness in the sufficient category, namely 21 respondents $(26.9 \%)$ while respondents who had received information from officers after counseling had knowledge of landslide preparedness in good category, namely 15 respondents $(19.2 \%)$. 
d Attitude of the Head of the Family in Jethi Village, Blimbing Village, Mojo Subdistrict, Kediri Regency After Being Provided Counseling

The attitude of the head of the family in Jethi Hamlet, Blimbing Village, Mojo District, Kediri Regency, was known that after counseling, almost half of the respondents had a landslide disaster preparedness attitude in the positive category, which was 47 respondents $(60.3 \%)$.

One of the factors that influence the success of counseling is the target factor, for example the level of education is too low so it is difficult to receive the message delivered, the socioeconomic level is too low so it does not pay much attention to the messages conveyed because it is more concerned with more urgent needs, beliefs and customs that have been embedded so that it is difficult to change it, the condition of the environment where the target lives is not likely to change behavior (Mubarak, 2007).

The results showed that after being given counseling there was an increase in the attitude of respondents where some respondents were negative to be positive. This condition is caused by the provision of counseling not only to provide information to respondents but also provide motivation to respondents.

The tabulation results show that respondents with jobs as farmers / farm laborers after extension have attitudes of landslide disaster preparedness in the negative category, namely 15 respondents $(19.2 \%)$. This condition shows that respondents who work as farmers tend to be more difficult to change their attitudes in the implementation of disaster preparedness so that the attitude of respondents does not change and tends to remain negative. In addition, people who were $>10$ years old living in the area had an attitude in the negative category, namely 27 respondents $(34.6 \%)$. This shows that counseling and length of stay also affect the attitude of the head of the family but these attitudes cannot be changed completely because they feel that they have been in the area since childhood and they also have no other place to live than in the area

e The Influence of Providing Counseling on Preparedness of Landslide Disasters Against Knowledge of Family Heads in Jethi Village, Blimbing Village, Mojo District, Kediri Regency

The results of statistical tests using Willcoxon signed rank test showed that there was a significant effect of providing counseling on landslide disaster preparedness on the knowledge of the head of the family in Jethi Village, Blimbing Village, Mojo Subdistrict, Kediri Regency.

Knowledge of the head of the family before being given counseling had enough knowledge in the category of 32 respondents, namely $41 \%$ and knowledge in the category of less, namely $37.2 \%$. After being given counseling knowledge of respondents in the less category decreased to $9 \%$ and respondents who had sufficient knowledge in the category increased to $47.4 \%$.

Based on the results of the analysis it can be seen that counseling has a significant influence on knowledge about disaster preparedness, this is because counseling is a process or effort carried out so that the community in this study is the head of the family, can better understand the disaster preparedness efforts, this is important considering the respondents live in areas prone to landslides.

f The Influence of Providing Counseling on Preparedness of Landslide Disasters Against the Attitudes of Family Heads in Jethi Village, Blimbing Village, Mojo District, Kediri Regency 
The results of statistical tests using the McNemar test showed that there was a significant effect of providing counseling on landslide disaster preparedness on the attitude of the head of the family in Jethi Village, Blimbing Village, Mojo District, Kediri Regency.

Counseling can significantly change the attitude of the people who were originally negative changed to positive, this was because respondents who received counseling gained enlightenment that preparedness was important to be carried out, especially in the counseling process researchers were accompanied by community leaders who were considered important in the community so that the respondents appeared to be able to be better in implementing disaster preparedness

\section{CONCLUSION}

There is a significant effect of providing counseling on landslide disaster preparedness to the knowledge of the head of the family in Jethi Village, Blimbing Village, Mojo District, Kediri Regency

There is a significant effect of providing counseling on landslide disaster preparedness on the attitude of the family head in Jethi Village, Blimbing Village, Mojo District, Kediri Regency.

\section{REFERENCES}

Azwar, S. (2005). Sikap Manusia : Teori Dan Pengukurannya. Yogyakarta : Pustaka Pelajar

BNPB. (2014). "Data \& Informasi Bencana Indonesia". (online), (http://dibi.bnpb.go.id/dinventar/showdatacard.jsp?clave=2900\&nStart=0) .Diakses tanggal 28 Februari 2015. pukul 00.30 WIB

Djafar. (2013). Pengaruh Penyuluhan Tentang Kesiapsiagaan Bencana Banjir Terhadap Pengetahuan Dan Sikap Kepala Keluarga Di Desa Romang Tangaya Kelurahan Tamangapa Kecamatan Manggala Kota Makassar. Universitas Hasanudin. Makasar.

Dwikorita, Karnawati. (2005). Bencana Alam Gerakan Massa Tanah Di Indonesia Dan Penanggulangannya. UGM : Yogyakarta Geologi.

Mubarak. (2007). Promosi Kesehatan : Sebuah Pengantar Proses Belajar Mengajar Dalam Pendidikan. Yogyakarta : Graha Ilmu

Muslihati, I., Lisandy, Y., Kasanah, R., \& Winarko, H. (2018). Effect Of Education Media Video On Improve Stroke Prevention Behavior In Continued Age In Wiyurejo Pujon Malang. Journal Of Nursing Practice, 1(2), 12-17. https://doi.org/10.30994/jnp.v1i2.28

Notoatmodjo. (2007). Promosi Kesehatan Dan Ilmu Perilaku. Jakarta: Rineka Cipta

Notoatmodjo. (2010). Promosi Kesehatan Teori dan Aplikasinya. Cetakan 2. Jakarta : Rineka Cipta.

Ramli, S. (2012). Pedoman Praktis Manajemen Bencana. Jakarta : Dian Rakyat 